(C) 2016 This manuscript version is made available under the CC-BY-NC-ND 4.0 license http://creativecommons.org/licenses/by-nc-nd/4.0

\title{
1 SULFATE SOILS STABILIZATION WITH MAGNESIUM-BASED BINDERS
}

2

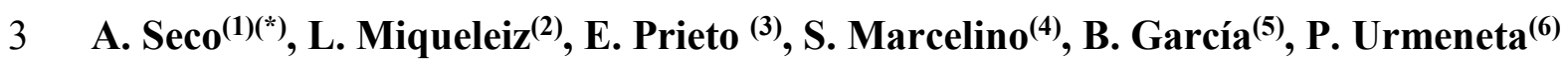

$5 \quad{ }^{(1)}$ Dept. of Projects and Rural Engineering. Public University of Navarre. 31006

6 Pamplona, Spain. (E-mail: andres.seco@unavarra.es. Phone: 34948169682; Fax:

$7 \quad 34948169148)$

$8 \quad{ }^{(2)}$ Dept. of Projects and Rural Engineering. Public University of Navarre. 31006

9 Pamplona, Spain. (E-mail: 1miqueleiz@gmail.com. Phone: 34948169682; Fax:

$10 \quad 34948169148)$

$11{ }^{(3)}$ Dept. of Projects and Rural Engineering. Public University of Navarre. 31006

12 Pamplona, Spain. (E-mail: epc@unavarra.es. Phone: 34948169682; Fax: 34948169148)

$13{ }^{(4)}$ Dept. of Projects and Rural Engineering. Public University of Navarre. 31006

14 Pamplona, Spain. (E-mail: sara.marcelino@unavarra.es. Phone: 34948169224; Fax:

$15 \quad 34948169148)$

$16{ }^{(5)}$ Ingeniería Cartográfica, Geodésica y Fotogrametría. Universidad del País Vasco.

1701006 Vitoria-Gasteiz, Spain. (E-mail: benat.garcia@ehu.eus. Phone: 34948169682;

18 Fax: 34948169148)

$19{ }^{(6)}$ Magnesitas Navarras S.A. 31630 Zubiri, Spain. (E-mail:

20 p.urmeneta@magnesitasnavarras.es. Phone: 34948421617; Fax: 34948421646)

21

22

${ }^{(*)}$ Corresponding author 


\section{ABSTRACT}

Sulfate soils' stabilization is a very interesting subject with technical, economic and environmental implications. The difficulty of their stabilization is due to the fact that the usual stabilizer additives are based on calcium. In these soils, sulfate combines with the calcium from the additive and the aluminum from the clay, resulting in a highly hydrated expansive mineral named ettringite. This provokes the swelling of the treated material and even its destruction. This study analyzes the result of the substitution of the calcium based additives by one alternative additive based on magnesium, an industrial byproduct named PC-8, in the stabilization of five different sulfate soils. From a mechanical point of view soils treated with PC-8 reached similar resistance values to the lime treated ones, of about 2-3 MPa for 4\% dosage and 2-5 MPa for $8 \%$ dosage, being usually better with the PC- 8 results than with the lime ones. When PC- 8 was combined with GGBS the resistance values increased up to 11-13 MPa and the lime-GGBS reached the 6-7 MPa.

40 The natural swelling of the soils treated with PC-8 decreased substantially and maintained constant even for immersion at long-term. In the case of the soils treated with lime, longterm swelling increased up to very high values even in the case of soils without natural swelling. XRD analysis of these samples demonstrated the existence of ettringite in 4 of the 5 soils when they were treated with lime and there was not expansive minerals in the PC-8 treated soils, agreeing with the swelling observed behavior of the soils when treated with both additives.

\section{HIGHLIGHTS}

There is a potential in using magnesium oxide as a sulfate soils stabilizer. 
Magnesium oxide demonstrated a better ability as pozzolanic activator to GGBS than

51 lime.

The long-term swelling test was a good estimator of the development of expansive minerals.

XRD results agree with the indirect estimation of the presence of expansive minerals.

All the lime and none of the PC-8 treated soils, showed expansive behavior.

KEYWORDS

Sulfate soil; soil stabilization; valorization; construction material; ettringite

\section{INTRODUCTION}

61 Soils' stabilization based on lime or cement is a widely used technique to improve the soils' properties as a construction material. The use of these additives is particularly suitable in clayey soils, which usually have inadequate properties like high plasticity, bad workability as well as low bearing capacity (Guney et al., 2007; Lin et al., 2007; Göktepe et al., 2008). Clayey soils consist in aluminosilicate mineral layers with negative surface charge that, by electrostatic repulsion, maintain an open structure. With the addition of

67 lime, $\mathrm{Ca}^{2+}$ ions fixation takes place, electrostatic charges of the clay layers are balanced and electrochemical repulsion forces between them are reduced. This causes the adhesion

69 of the clay particles in flocs where the clay layers are now linked by $\mathrm{Ca}^{2+}$ ions, resulting 70 in a soil with improved properties: a more granular structure, higher permeability and 71 lower plasticity (Kinuthia et al., 1999; Lin et al., 2007). In addition, the lime's hydration releases $\mathrm{OH}^{-}$ions that increase the $\mathrm{pH}$ up to about 12.4. Under these conditions pozzolanic reactions take place in the soil: Aluminum (A) and silicon (S) from the clay matrix are 
cementitious compounds schematically named CSH, CAH and CSAH (Nalbantoglu, 2004; Guney et al., 2007; Yong and Ouhadi, 2007; Chen and Lin, 2009). These compounds are responsible of the improvement of the mechanical properties of the stabilized soil upon curing time, as pozzolanic reactions develop. The kinetics of these reactions depend on the amount and availability of the concerned oxides and they can last even years (Wild et al., 1998). The clay matrix usually has enough aluminum and silicon, which allows the use of lime instead of cement, being a cheaper and effective treatment (Chen and Lin, 2009). In those soils where enough silicon and aluminum are not available, they have to be added with the additive. In these cases it is recommended the use of products like Ordinary Portland Cement (OPC), rich in available $\mathrm{SiO}_{2}, \mathrm{Al}_{2} \mathrm{O}_{3}$ and $\mathrm{CaO}$, that provides the needed oxides, shortening also the reaction time (Wild et al., 1998; Degirmenci et al., 2007). The improvement of the obtained properties will depend on the quantity and richness of the additive, the soil's mineralogy, its particles' size and shape and the curing conditions (Misra et al., 2005; Yarbasi et al., 2007; Göktepe et al., 2008).

Despite the demonstrated technical, economic and environmental suitability of the use of calcium based additives as stabilizers for soils, this type of treatment may cause adverse effects in some soils and even lead to the total destruction of the stabilized material. One of the most common causes of this type of failure is the presence in the stabilized soil of sulfate $\left(\mathrm{SO}_{4}^{2-}\right)$. Sulfate is a very common oxide as well as in many natural soils around the world as in industrial wastes. Other times it may stem from the water used for compaction, or arise from infiltration from the surrounding terrain. Whatever its origin, the reaction of the calcium supplied by the lime or cement, aluminum, silicon and the sulfate all together in the presence of water, causes the formation of expansive minerals, the most common being a highly hydrated and expansive crystalline mineral named ettringite $\left[\mathrm{Ca}_{6} \mathrm{Al}_{2}\left(\mathrm{SO}_{4}\right)_{3}(\mathrm{OH})_{12} \cdot 26 \mathrm{H}_{2} \mathrm{O}\right.$ ] (Crammond, 2002; Nobst and Stark, 2003; 
100 Ciliberto et al., 2008; Norman et al., 2013). The mechanics of the formation of ettringite

101 are not well established (Mohamed, 2000), although the conditions for its formation are

102 known (Ouhadi and Yong, 2003), which are: (1) High pH, (2) presence of soluble Al, (3)

103 presence of soluble $\mathrm{Ca}$, (4) presence of soluble sulfate and (5) availability of water. It is

104 also known that the rate of ettringite formation is accelerated by high temperatures

105 (Rajasekaran, 2005). Talero (2005) and Rahhal and Talero (2014) pointed out different

106 formation rates, shape and size of the ettringite's crystals based on different reactive

107 aluminum compounds from $\mathrm{OPC}\left(\mathrm{C}_{3} \mathrm{~A}\right)$ and pozzolanic additions $\left(\mathrm{Al}_{2} \mathrm{O}_{3}^{\mathrm{r}-}\right)$. Given the

108 right conditions, ettringite formation is the dominant reaction, even appearing during the

109 mixing of the materials. Mohamed (2000) determined the total time of formation of

110 ettringite in a natural marly soil within 48 hours. In their experiments Ouhadi and Yong

111 (2003) and (2008) established the formation of this mineral over one month in one case,

112 and between the mixture of the soil with lime and 48 hours in another experiment. From

113 a chemical point of view, the reactions involved in the formation of ettringite are (Ouhadi

114 and Yong, 2008):

$115 \mathrm{CaO}+\mathrm{H}_{2} \mathrm{O} \rightarrow \mathrm{Ca}(\mathrm{OH})_{2}$

$116 \mathrm{Ca}(\mathrm{OH})_{2} \rightarrow \mathrm{Ca}^{2+}+2(\mathrm{OH})^{-}$

$117 \mathrm{Al}_{2} \mathrm{Si}_{4} \mathrm{O}_{10}(\mathrm{OH})_{2} \cdot n \mathrm{H}_{2} \mathrm{O}+2(\mathrm{OH})^{-}+10 \mathrm{H}_{2} \mathrm{O} \rightarrow 2\left\{2 \mathrm{Al}(\mathrm{OH})_{4}^{-}+4 \mathrm{H}_{4} \mathrm{SiO}_{4}\right\}+n \mathrm{H}_{2} \mathrm{O}$

$\mathrm{M}_{x} \mathrm{SO}_{4} \cdot n \mathrm{H}_{2} \mathrm{O} \rightarrow X M^{y}+\mathrm{SO}_{4}+n \mathrm{H}_{2} \mathrm{O}$

where

$118 x=1, y=2$

or

$x=2, y=1$

$6 \mathrm{Ca}^{2+}+2 \mathrm{Al}(\mathrm{OH})_{4}^{-}+4 \mathrm{OH}^{-}+3\left(\mathrm{SO}_{4}^{2-}\right)+26 \mathrm{H}_{2} \mathrm{O} \rightarrow \mathrm{Ca}_{6} \mathrm{Al}_{2}\left(\mathrm{SO}_{4}\right)_{3}(\mathrm{OH})_{12} \cdot 26 \mathrm{H}_{2} \mathrm{O}$ 
121 A second way for the ettringite formation has been observed in OPC mortars and

122 concretes where, after long curing periods in wet conditions, sulfate attacks the CAH,

123 generating what is commonly refered to as "delayed ettringite", which provokes the same

124 undesirable effects in the cementitious materials (Lee et al., 2005; Escadeillas et al., 2007;

125 Ciliberto et al., 2008; Chen and Jianj, 2009; Pavoine et al., 2012; Nguyen et al., 2013).

126 The swelling capacity of the soil in which ettringite develops, and therefore its

127 undesirable effects, are produced during the formation of this mineral. Once ettringite is

128 present in the soil, it is stable and even contributes to improve bearing capacity (Kinuthia

129 et al., 1999; Rajasekaran 2005; Min et al., 2008).

130 One way to reduce the formation of ettringite in a stabilized sulfate soil is the partial

131 substitution of lime or cement by Ground Granulated Blastfurnace Slag (GGBS). GGBS

132 contributes with a large amount of quickly available aluminum and silicon both of which

133 react with the available calcium, expending it for the cementitious gels formation,

134 avoiding the formation of ettringite. This protective effect against sulfate attack is

135 especially intense for high replacement ratios of lime with GGBS (about 83\%).

136 Furthermore, GGBS also produces a denser cementitious matrix, reduces the permeability

137 and hence the water availability, increasing the durability against the internal and external

138 sulfates' attack (Wild et al., 1998; Tasong et al., 1999; Obuzor et al., 2012). However this

139 way of limiting the sulfate attack must to be used carefully because all the oxides needed

140 for the ettringite formation remain in the treated material (Celik and Nalbantoglu, 2013).

141 Another probable way to stabilize the sulfate soils can be the replacement of calcium

142 based additives by other metal cations, such as magnesium. Xeidakis (1996-a) and (1996-

143 b) demonstrated that the $\mathrm{Mg}(\mathrm{OH})_{2}$ fixing in the expansive clay layers is more rapid than

144 that $\mathrm{Ca}(\mathrm{OH})_{2}$, resulting also in the clay's flocculation. He also proved the $\mathrm{Mg}(\mathrm{OH})_{2}$ 
145 capacity to increase the soil's $\mathrm{pH}$ and the theoretical possibility to generate $\mathrm{Mg}$ based

146 cementitious gels.

147 The lack of guaranties about the sulfate soils stabilization with calcium additives, the

148 magnesium capacity to flocculate clays and its eventually cementing properties, both

149 make the magnesium-based additives a priority research subject.

150 This study analyzes the possibility to stabilize sulfate-containing soils with magnesium-

151 based additives instead the calcium-based ones, taking into account the capacity to create 152 cementitious gels as well as the reduced potential for the formation of expansive minerals 153 due to the stabilization of both additives.

155 2. MATERIALS AND METHODS

156 2.1. MATERIALS

157 Three natural soils (I, II and III) and two based in waste artificial soils (IV and V) were

158 considered in this study. Table 1 shows the characterization of the analyzed soils from a

159 soil mechanics and chemical points of view. All the laboratory test were carried out in

160 accordance with Spanish and European Standards, mineralogical compositions were

161 estimated by X-Ray Diffraction (XRD) analysis based on the chart proposed by Al-

162 Rawas (1999) and the soils composition, expressed as their most significant oxides, were

163 based on X-Ray Fluorescence (XRF) analysis.

164

165

TABLE 1

166

167 Soils I, II and III were obtained from different geological formations across the Ebro's

168 Valley in the North of Spain. They are expansive clayey soils from different geological

169 terciary structures with different sulfate contents. 
170 Soil IV comes from the fraction smaller than $5 \mathrm{~mm}$, obtained from crushing of old 171 concrete structures in a building site in the city of Pamplona (Spain). This recycled 172 material contains a $5 \%$ of sulfate, mainly because of the plasterboards remains crushed

173 together with the concrete. Soil V consists of a mix of a $70 \%$ slag from a biomass plant

174 that burns cereal straw, with a $30 \%$ of a local marly soil to get adequate workability 175 properties for the soils mechanical tests.

176 The second kind of materials considered are the following additives: (1) PC-8. This 177 material is a by-product rich in $\mathrm{MgO}$ calcined during magnesite production by means of 178 the calcination of natural $\mathrm{MgCO}_{3}$ rocks up to $1,100^{\circ} \mathrm{C}$. This process is carried out in a 179 rotatory kiln with crosscurrent air circulation, which pulls dust particles along the whole 180 kiln. So that, this dust contains $\mathrm{MgCO}_{3}$ (inert), calcined $\mathrm{MgO}$ (reactive) and vitrified $\mathrm{MgO}$ 181 (inert) particles and it is recovered by means of air cyclones. The sample used in this study was supplied by Magnesitas de Navarra S.A. Company. (2) Commercial hydrated lime CL-90-S. Rich in $\mathrm{Ca}(\mathrm{OH})_{2}$, it has been used like reference calcium based additive

184 for the soils treatment, and (3) GGBS. This by-product of the steel production has been 185 used combined with PC-8 and lime as activators. The sample used was supplied by 186 Hanson Cement Company.

187 Table 2 shows the additives' properties and their XRF obtained oxide composition.

\section{TABLE 2}

191 In the case of the soils the only pre-treatment made consisted on grinding and sieving to get particles sizes smaller than $2 \mathrm{~mm}$ to allow a better contact soil-additive and thus, a more efficient treatment. In the case of the additives no pre-treatment was necessary. 
196 Two kind of samples were prepared during the experimental investigation: The first category are the samples to establish the mechanical properties of the tested combinations. The mixing of soils and additives was carried out in an industrial mixer until their complete homogenization. After that, water corresponding to the Normal Proctor (NP) test was added slowly to get uniform distribution. After a wet mixing time the mixes were treated in a high speed homogenizer to guarantee good of mixing and wet distribution. Once the quality of the mixes was visually verified, $65 \mathrm{~mm}$ diameter and $75 \mathrm{~mm}$ height cylindrical samples were prepared, pressing the material in a mold at $8 \mathrm{MPa}$. The samples were immediately demolded after fabrication and maintained, since the fabrication till the testing age, in a wet chamber at $20^{\circ} \mathrm{C}$ and $100 \% \mathrm{HR}$. The additives' doses were established based on the bibliography as follows (Oti et al., 2008; Seco et al., 2011a; Seco et al., 2011b; Miqueleiz et al., 2012): Soils I, II and III were treated with PC-8 at 4 and $8 \%$, lime at 4 and $8 \%$, PC- 8 at $2 \%$ plus GGBS at $8 \%$ and lime at $2 \%$ plus GGBS at $8 \%$. In the case of the soils IV and V, PC-8 and lime alone were not tested because of the lack

210 of clay minerals in the crushed concrete and in the biomass slags. In these soils only PC-

2118 at $2 \%$ plus GGBS at $8 \%$ and lime at $2 \%$ plus GGBS at $8 \%$ were used.

212 The combinations with $8 \%$ of calcium and magnesium alone where picked out to state

213 the long-term stability of the treated soils against the sulfate attack. In this case, $50 \mathrm{~mm}$

214 diameter and $2 \mathrm{~mm}$ height samples were prepared at NP maximum density and optimum

215 wet content inside oedometer sample rings. In these cases, as the materials quantities were

216 small (about $200 \mathrm{~g}$ in each case), the mixing as well as the compaction procedures were

217 performed manually in accordance with the Spanish standard UNE 103601. 
220 The characterization of the mechanical properties of the tested samples was carried out at

221 the ages of $1,7,14,28,56$ and 90 days, according to the unconfined compressive test

222 defined in the Spanish standard UNE 103400. The long-term materials stability was

223 analyzed in two ways: On the one hand the dimensional stability of the samples in a long-

224 term swelling was determined by immersion in the oedometer test according to the

225 Spanish standard UNE 103601. On the other hand, all the samples, after the swelling test

226 were analyzed by XRD to identify any possible mineralogical changes in the samples'

227 composition, especially the development of expansive minerals.

228

229

3. RESULTS AND DISCUSSION

230

\subsection{MECHANICAL PROPERTIES INVESTIGATION}

231 Figure 1 shows the samples' mechanical properties for the five soils considered and the different additives combinations.

In the soils I-III the use of $4 \%$ of lime and of PC- 8 gave the lowest resistance values with no significant differences among both additives. The dosage of $8 \%$ of PC- 8 resulted in low or moderate mechanical strength increases that always maintain under $5 \mathrm{MPa}$. In the case of the lime only in soil III a small increase of resistance was observed for the 90 days curing time. For the combinations with $2 \%$ of lime or PC- 8 combined with $8 \%$ GGBS,

241 the resistance increases were the most significant, especially in the case of the PC-8 that,

242 in all the soils was beyond $11 \mathrm{MPa}$, with a maximum value of $13.4 \mathrm{MPa}$ in soil IV. Lime plus GGBS treated soils demonstrated good increase in mechanical properties but always

244 lower than for the PC-8 plus GGBS combinations, with typical values about 6-7 MPa and 
a maximum value of $8.8 \mathrm{MPa}$ in soil III at 56 days. Another meaningful data is that, in all

246 the cases, close to maximum resistance values were reached before the 28 days,

247 shortening significantly the expected curing time for soils stabilization. Finally, the lack

248 of visual damage in the specimens during the 90 days of curing should be noted. Only in

249 samples from the combinations of soil I, with 4 and $8 \%$ of lime, where some surface

250 spalling was observed (see Figure 2), but their XRD analyzes did not show any presence 251 of ettringite.

FIGURE 2

255 After the experimental investigations the remaining samples of all the combinations were maintained in the wet chamber for observing the possible delayed appearance of damages caused by expansive minerals. In soils I-VI no defects were identified but in the case of soil $\mathrm{V}$ at 90 days small surface cracks, which did not affect the mechanical strength of the samples, were observed. These cracks in the samples treated with lime continued growing up till 140 days of curing, when all the samples treated with lime and with PC-8 had the appearance shown in Figure 3. Despite the evidence of the existence of expansive behaviour, the XRD analyses of these samples did not identify any changes in mineralogical composition that supported the appearance of expansive minerals. Figure 4 shows the XRD difractograms of soil V and the same soil treated with $8 \%$ lime, tested 265 after the unconfined compressive test.

FIGURE 3 


\subsection{ANALYSIS FOR LONG-TERM DIMENSIONAL STABILITY}

271 Following the stated methodology, three samples of each soil with $8 \%$ of lime, $8 \%$ of PC-

2728 and samples without treatment (control), were prepared to analyze their free swelling 273 upon potential in immersion. Figure 5 shows the temporal evolution of the different 274 combinations and Table 3 summarizes them.

\section{FIGURE 5}

\section{TABLE 3}

The five soils showed similar behavior. The untreated samples maintained steady swelling values except soil $\mathrm{V}$. This behavior was attributed to the presence of unburned vegetal remains in the biomass slag that swelled because of their water absorption or because of the presence of calcium and sulfate from the burnt remains that could combine with aluminum oxides from the marl, to produce small amounts of ettringite. The swelling for the soils treated with PC-8, decreased significantly, even reaching acceptable values for use as construction materials. During the entire testing time, these values remained steady except for soil IV where a slight swelling was observed, probably because of the formation of small quantities of ettringite from the cement compounds and the available sulfate. The low swelling values obtained in the samples treated with PC- 8 demonstrated the good properties of $\mathrm{MgO}$ like expansive clays floculator as well as the elimination of swelling effects, even in the case of high dosages (8\%), in immersion and at long-term. In the case of the natural soils (I-III), the treatment with lime decreased their natural swelling during the first 24 hours but after that, they swelled up to values much above their natural ones. In soils I and II, the samples swelling increased during all the test duration but in the case of the soil III, its swelling reached its maximum value at the age 
of 10 days remaining steady afterward, probably due to the whole sulfate's consumption

296 because of its small amount $(0.30 \%)$. Soils IV and V treated with lime also presented

297 significant continuous swelling values during the test duration despite their lack of natural swelling.

\subsection{MINERALOGIC ANALYSIS OF THE SAMPLES}

301 After observing macroscopic swelling behavior of the treated samples, they were analyzed by XRD to establish the relationship between the observed swelling and the presence of expansive minerals. XRD demonstrated the presence of ettringite in samples of soils I, II, IV and V treated with lime. Figure 5 shows how peaks of ettringite appear in the difractograms of these soils, revealing the presence of this mineral. These results agree in all the cases with the swelling observed behavior in the dimensional stability analysis of the samples, except in the case of the soil III. This fact, together with to the small size of the ettringite's peaks in the difractograms of the other soils where this mineral was observed, suggests that the observed type of ettringite has a low crystalline

310 structure or more probably, it appears in small amounts, possibly in specific sites of the

311 samples, making its identification more difficult from a mineralogical point of view, even

312 when its macroscopical effects are evident.

316 As it can be seen in the Figure 6, in the case of the samples treated with PC-8 no expansive

317 mineral was observed in any difractograms. The only difference with the soils' previous

318 XRD characterization difractograms were the magnesite $\left(\mathrm{MgCO}_{3}\right)$ peaks related to the 
319 additive's carbonation, agreeing with the macroscopical stability observed in the samples

320 in all the cases.

\section{CONCLUSIONS}

323 The stabilization of sulfate soils is a very interesting subject because of its technical,

324 economic and environmental implications. From a technical point of view their

325 stabilization continues being a challenge because of the concurrency on them many times 326 of circumstances that make them bad construction materials and the practical 327 impossibility of their stabilization with conventional additives. In this sense, the results 328 obtained in this study have allowed to answer some of the key questions about the effect 329 of the magnesium in different kinds of sulfate soils, among them:

330 1. The treatment of the natural soils with 4 and $8 \%$ of lime or PC-8 improved their mechanical properties up to usual values obtained in other clayey soils. In all the cases the developed resistances was higher for the $8 \%$ dosages than for the $4 \%$ ones, and for the PC-8 than for the lime, demonstrating the ability of the magnesium as a clay stabilizer additive from a mechanical point of view, better than the lime.

2. The use of a combined binder lime-GGBS or PC-8-GGBS improved in all the cases the mechanical properties of the treated soils, even before the 28 days curing time. PC-8-GGBS combinations reached, in all the treated soils, the best mechanical results at all the curing times, demonstrating a better ability of the magnesium as pozzolanic additives activator than the calcium.

3. None of the samples prepared for the unconfined compressive test showed significant damage or lack of resistance during the 90 days of curing time in the wet chamber. Only after that age did all the remaining samples of the soil V treated 
with lime start to swell during the 160 days of curing time, when they were completely disintegrated. The XRD analysis of these samples didn't show the presence of any expansive minerals in them.

4. The long-term swelling test demonstrated its ability to be an indirect estimator of analysis.

As final conclusion it can be stated that the use of magnesium-based additives can be a potentially good method for the valorization of sulfate containing materials in construction applications. Although more studies must to be carried out in this sense, the results obtained in this study allow suggest possible replacement of calcium based

360 additives by the magnesium ones.

\section{ACKNOWLEDGEMENTS}

363 This research has been supported by Research Project OTRI 2011021091 with

364 MAGNESITAS DE NAVARRA S.A. company.

\section{REFERENCES}

367 AENOR. Una Norma Española, 1996, Ensayo del hinchamiento libre de un suelo en edómetro, UNE 103601. 
369 AENOR. Una Norma Española, 1993, Ensayo de rotura a compresión simple en probetas 370 de suelo, UNE 103400.

371 Al-Rawas, A., 1999. The factors controlling the expansive nature of the soils and rocks

372 of northern Oman. Engineering Geology 53 (3-4), 327-350.

373 Chen, J.K., Jianj, M.Q., 2009. Long-term evolution of delayed ettringite and gypsum in

374 Portland cement mortars under sulfate erosion. Construction and Building Materials, 23, $375 \quad 812-816$.

376 Celik, E., Nalbantoglu, Z., 2013. Effects of ground granulated blastfurnace slag (GGBS)

377 on the swelling properties of lime-stabilized sulfate-bearing soils. Engineering Geology, $378 \quad 163,20-25$.

379 Chen, L., Lin, D-F., 2009. Stabilization treatment of soft subgrade soil by sewage sludge 380 ash and cement, Journal of Hazardous Materials, 162(1), 321-327.

381 Ciliberto, E., Ioppolo, S., Manuella, F., 2008. Ettringite and Thaumasite: A chemical 382 route for their removal from cementious artefacts. Journal of Cultural Heritage, 9, 30-37.

383 Crammond, N., 2002. The occurrence of thaumasite in modern construction - a review.

384 Cement and Concrete Composites, 24(3-4), 393-402.

385 Degirmenci, N., Okucu, A., Turabi, A., 2007. Application of phosphogypsum in soil 386 stabilization. Building and Environment 42 (9), 3393-3398

387 Escadeillas, G., Aubert, J.E., Segerer, M., Prince, W., 2007. Some factors affecting 388 delayed ettringite formation in heat-cured mortars. Cement and Concrete Research, 37, $389 \quad 1445-1452$.

390 Göktepe, A. B, Sezer, A., Sezer, G.I., Ramyar, K., 2008. Classification of time-dependent 391 unconfined strength of fly ash treated clay. Construction and Building Materials, 22(4), $392 \quad 675-683$. 
393 Guney, Y., Sari, D., Cetin,M., Tuncan, M., 2007. Impact of cyclic wetting-drying on

394 swelling behavior of lime-stabilized soil. Building and Environment 42 (2), 681-688.

395 Kinuthia, J. M., Wild, S., Jones, G. I., Effects of monovalent and divalent metal sulphates

396 on consistency and compaction of lime-stabilised kaolinite, Applied Clay Science,

397 Volume 14, Issues 1-3, February 1999, Pages 27-45

398 Lee, H., Cody, R.D., Cody, A.M., Spry, P.G., 2005. The formation and role of ettringite

399 in Iowa highway concrete deterioration, Cement and Concrete Research, 35, 332-343.

400 Lin, D.F., Lin, K.L., Hung, M.J., Luo, H.L., 2007. Sludge ash/hydrated lime on the 401 geotechnical properties of soft soil. Journal of Hazardous Materials 145 (1-2), 58-64.

402 Min, Y., Jueshi, Q., Ying, P. Activation of fly ash lime systems using calcined 403 phosphogypsum. Construction and Building Materials, Volume 22, 2008, Pages 10044041008.

405 Miqueleiz, L., Ramírez, F., Seco, A., Nidzam, R.M., Kinuthia, J.M., Abu Tair, A., Garcia, 406 R., 2012. The use of stabilised Spanish clay soil for sustainable construction materials. 407 Engineering Geology, 26, (133-134), 9-15.

408 Misra, A., Biswas, D., Upadhyaya, S., 2005. Physico-mechanical behavior of 409 selfcementing class C fly ash-clay mixtures. Fuel 84 (11), 1410-1422.

410 Mohamed, A. M. O. The role of clay minerals in marly soils on its stability, Engineering 411 Geology, Volume 57, Issues 3-4, July 2000, Pages 193-203.

412 Nalbantoglu, Z., 2004. Effectiveness of Class C fly ash as an expansive soil stabilizer.

413 Construction and Building Materials 18 (6), 377-381.

414 Nguyen, V. H., Leklou, N., Aubert, J. E., \& Mounanga, P., 2013. The effect of natural 415 pozzolan on delayed ettringite formation of the heat-cured mortars. Construction and 416 Building Materials, 48, 479-484. 
417 Nobst, P., Stark, J., 2003. Investigations on the influence of cement type on thaumasite

418 formation. Cement and Concrete Composites, 25(8), 805-1210.

419 Norman, R.L., Dann, S.E., Hogg, S.C., Kirik, C.A., 2013. Synthesis and structural 420 characterisation of new ettringite and thaumasite type phases: $421 \mathrm{Ca}_{6}\left[\mathrm{Ga}(\mathrm{OH})_{6} \cdot 12 \mathrm{H}_{2} \mathrm{O}_{2}\left(\mathrm{SO}_{4}\right) 3 \cdot 2 \mathrm{H}_{2} \mathrm{O}\right.$ and $\mathrm{Ca}_{6}\left[\mathrm{M}(\mathrm{OH})_{6} \cdot 12 \mathrm{H}_{2} \mathrm{O}\right] 2\left(\mathrm{SO}_{4}\right)_{2}\left(\mathrm{CO}_{3}\right)_{2}, \mathrm{M}=\mathrm{Mn}$, 422 Sn. Solid State Sciences, 25, 110-117.

423 Obuzor, G.N., Kinuthia, J.M., Robinson, R.B., 2012. Soil stabilisation with lime424 activated-GGBS-A mitigation to flooding effects on road structural 425 layers/embankments constructed on floodplains. Engineering Geology 151, 112-119.

426 Oti, J.E., Kinuthia, J.M., Bai, J., 2008. Using slag for unfired-clay masonry bricks. 427 Proceedings of ICE, Journal of Construction Materials 161 (4),147-155.

428 Ouhadi, V. R., Yong, R. N. The role of clay fractions of marly soils on their post 429 stabilization failure, Engineering Geology, Volume 70, Issues 3-4, Third British 430 Geotechnical Society Geoenvironmental Engineering Conference, November 2003, 431 Pages 365-375.

432 Ouhadi, V.R., Yong, R. N., Ettringite formation and behaviour in clayey soils. Applied 433 Clay Science, Volume 42, 2008, Pages 258-265.

434 Pavoine, A., Brunetaud, X., Divet, L., 2012. The impact of cement parameters on Delayed 435 Ettringite Formation. Cement \& Concrete Composites, 34, 521-528.

436 Rahhal, V., Talero, R., 2014. Very early age detection of ettringite from pozzolan origin. 437 Construction and Buildings Materials, 53, 674-679.

438 Rajasekaran, G. Sulphate attack and ettringite formation in the lime and cement stabilized 439 marine clays, Ocean Engineering, Volume 32, Issues 8-9, June 2005, Pages 1133-1159.

440 Seco, A., Ramírez, F., Miqueleiz, L., Garcia, B., Prieto, E,. 2011. The use of non441 conventional additives in Mares stabilization. Applied clay science 51 419-423. 
442 Seco A., Ramirez F., Miqueleiz, L., García B., 2011. Stabilization of expansive soils for 443 use in Construction. Applied Clay Science, 51(3), 348-352.

444 Talero R., 2005. Performance of metakaolin and portland cements in ettringite formation 445 as determined by ASTM C 452-68: kinetic and morphological differences. Cement and 446 Concrete Research, 32, 1269-84.

447 Tasong, W.A., Wild, S., Tilley, R., 1999. Mechanisms by which Ground Granulated 448 Blastfurnace Slag Prevents Sulphate Attack of Lime-Stabilised Kaolinite. Cement and 449 Concrete Research 29(7), 975-982

450 Wild, S., Kinuthia, J.M., Jones, G.I., Higgins, D.D., 1998. Effects of partial substitution 451 of lime with ground granulated blast furnace slag (GGBS) on the strength properties of 452 lime-stabilised sulphate-bearing clay soils. Engineering Geology 51 (1), 37-53.

453 Xeidakis, G.S., 1996a. Stabilization of swelling clays by $\mathrm{Mg}(\mathrm{OH})_{2}$. Factors affecting 454 hydroxy-Mg-interlayering in swelling clays. Engineering Geology 44 (1-4), 93-106.

455 Xeidakis, G.S., 1996b. Stabilization of swelling clays by $\mathrm{Mg}(\mathrm{OH})_{2}$. Changes in clay 456 properties after addition of Mg-hydroxide. Engineering Geology 44 (1-4), 107-120.

457 Yarbasi, N., Kalkan, E., Akbulut, S., 2007. Modification of the geotechnical properties, 458 as influenced by freeze-thaw, of granular soils with waste additives. Cold Regions 459 Science and Technology 48 (1), 44-54.

460 Yong, R.N., Ouhadi, V.R., 2007. Experimental study on instability of bases on natural 461 and lime/ cement-stabilized clayey soils. Applied Clay Science 35 (3-4), 238-249

462

463 FIGURES

464 Figure 1. Unconfined compression test results of soils. 


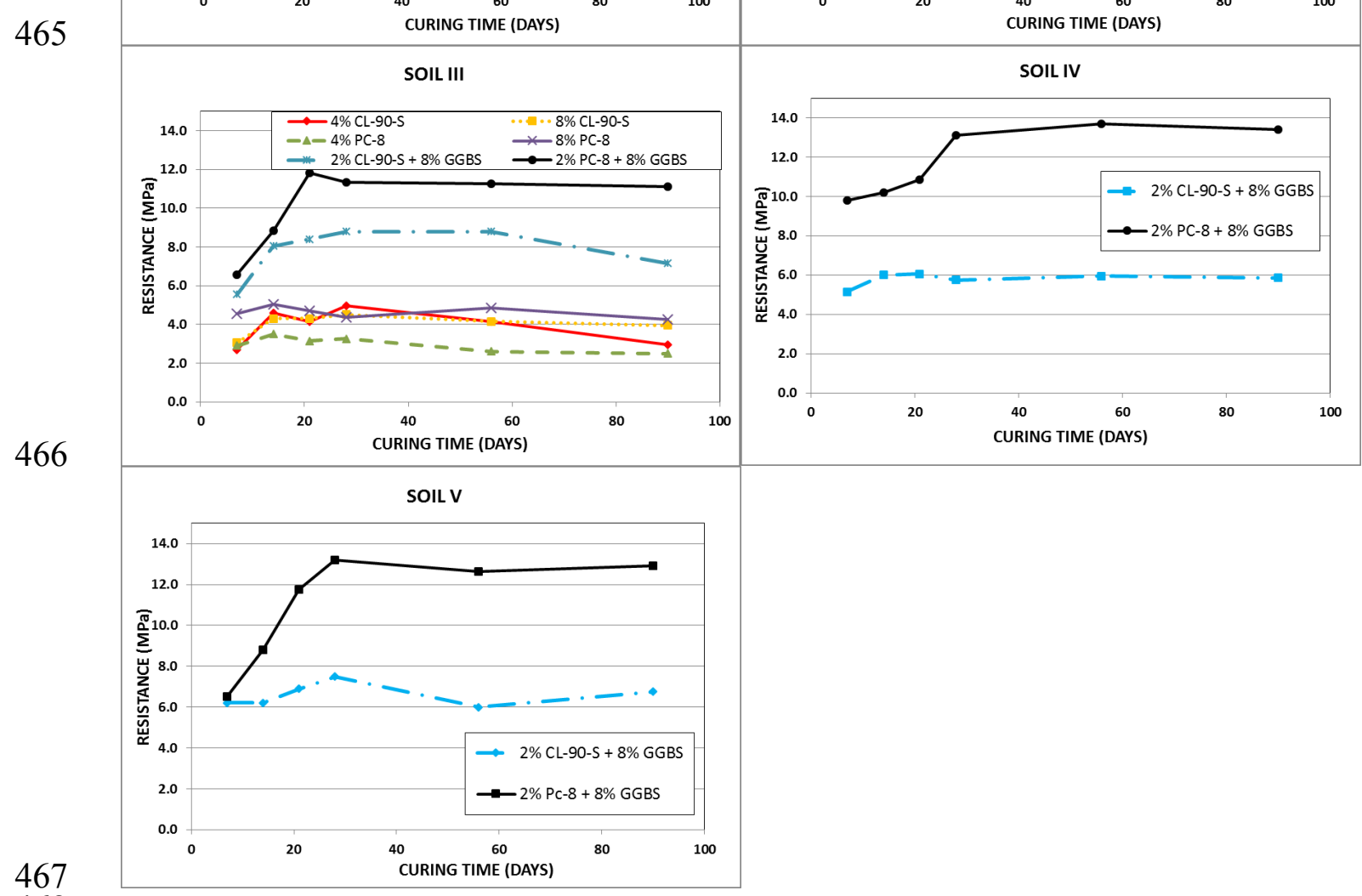

469 Figure 2. Soil 1 treated with $8 \%$ lime observed surface cracks at 90 days curing age. 


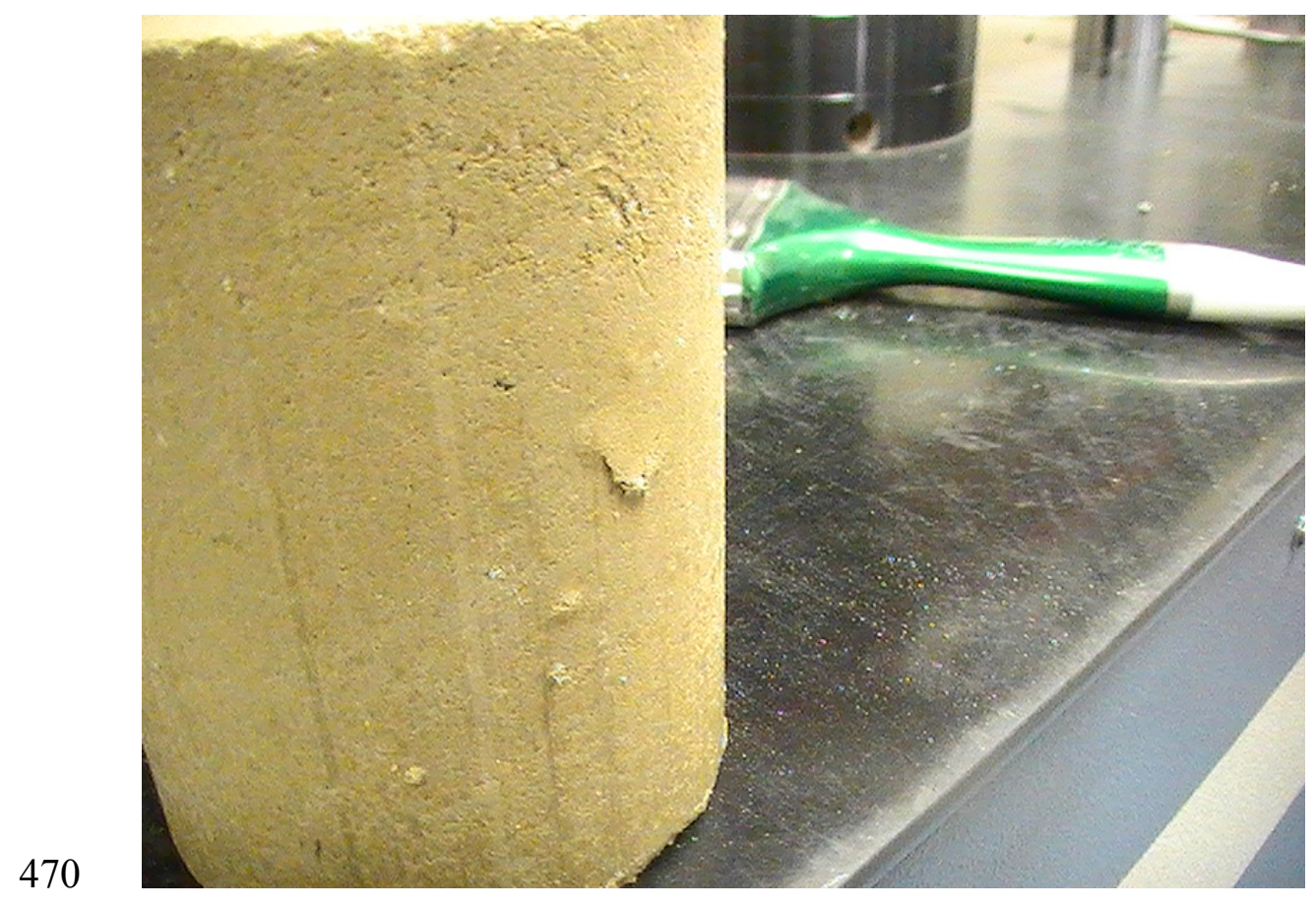

471

472 Figure 3. 140 days soil V samples. a) treated with $8 \%$ lime and b) treated with 8\% PC-8.

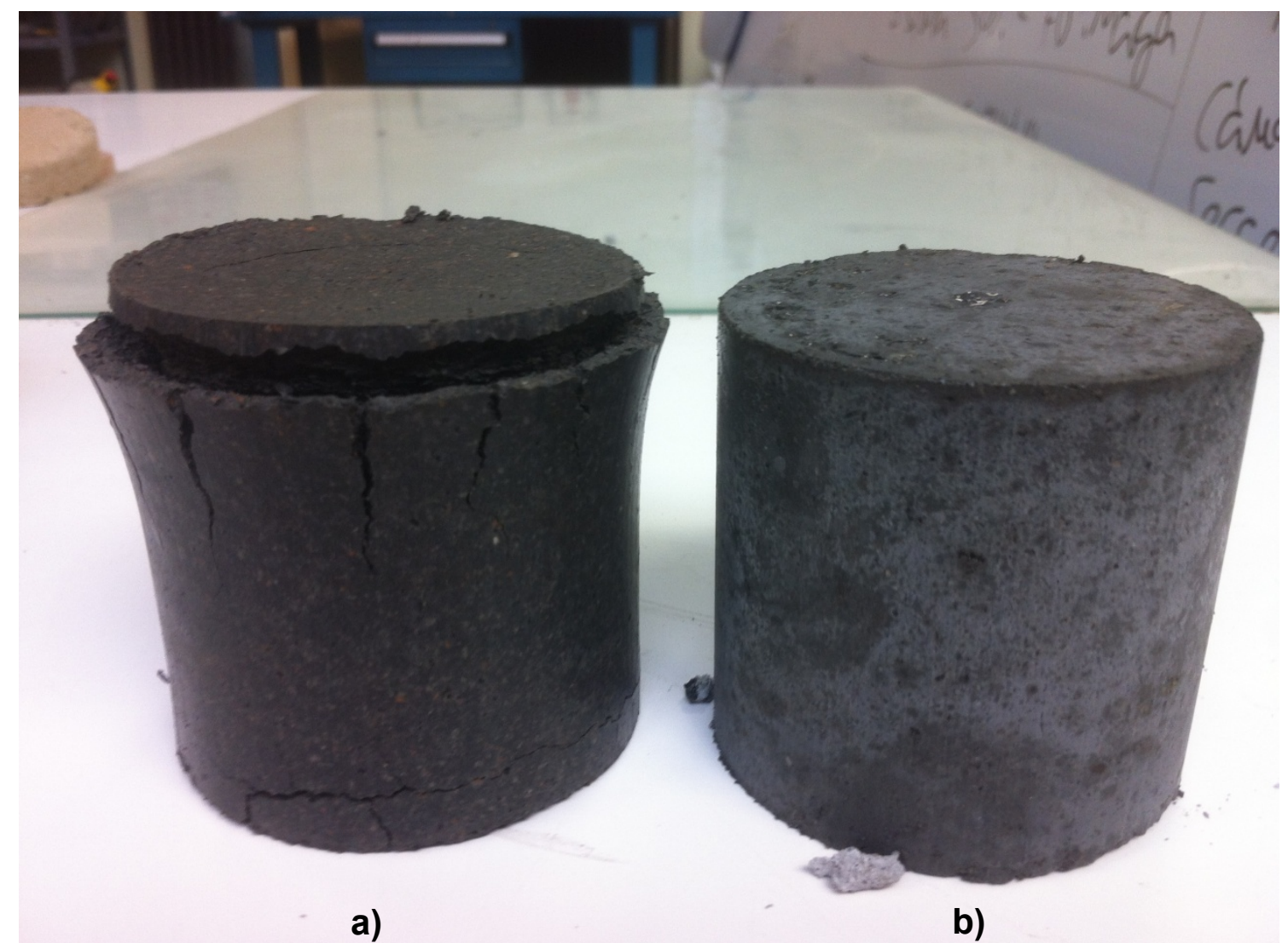

474 
475 Figure 4. XRD difractograms of soil $\mathrm{V}$ and soil $\mathrm{V}$ treated with $8 \%$ lime, after the 476 unconfined compressive test.

477

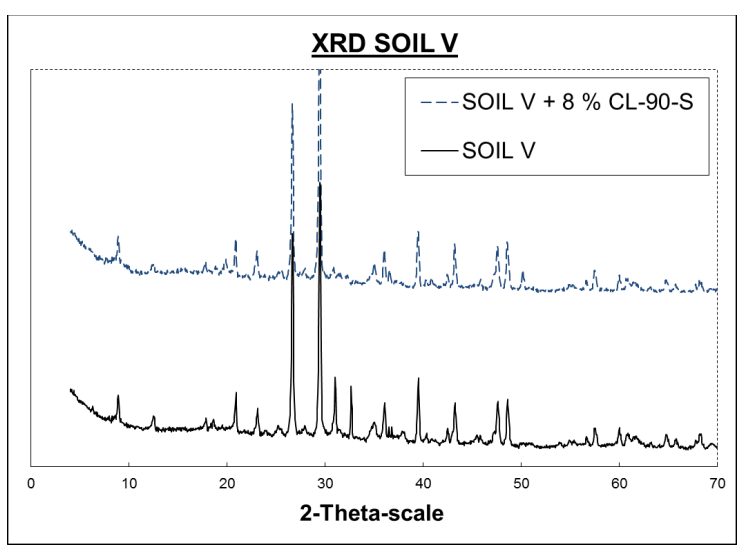

478

479 Figure 5. Long term dimensional stability analysis test results.

480
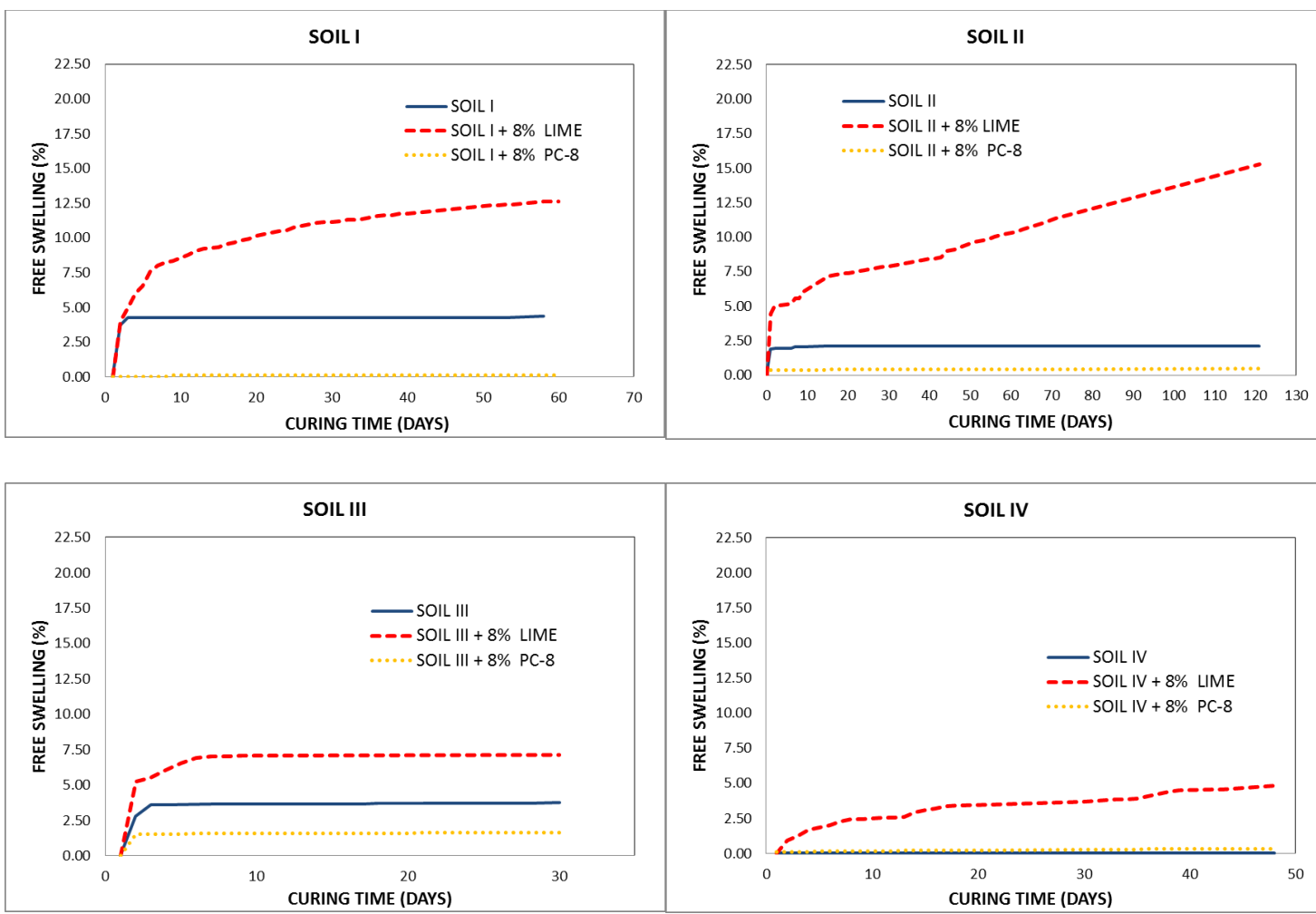


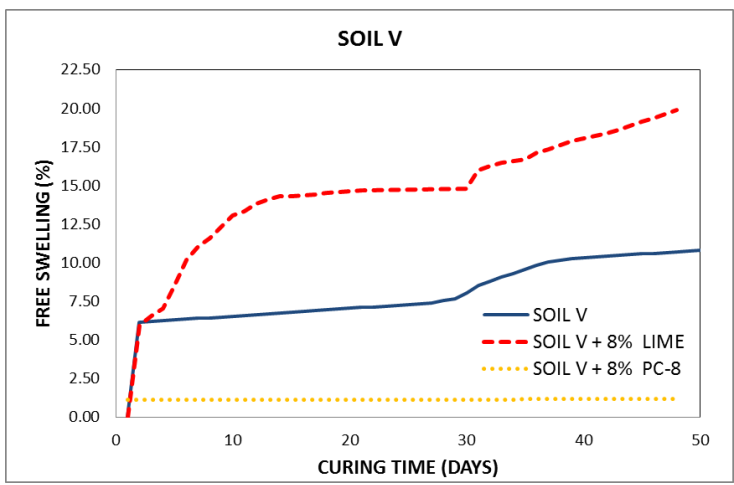

483

484 Figure 6. XRD of lime and PC-8 treated soils.

485
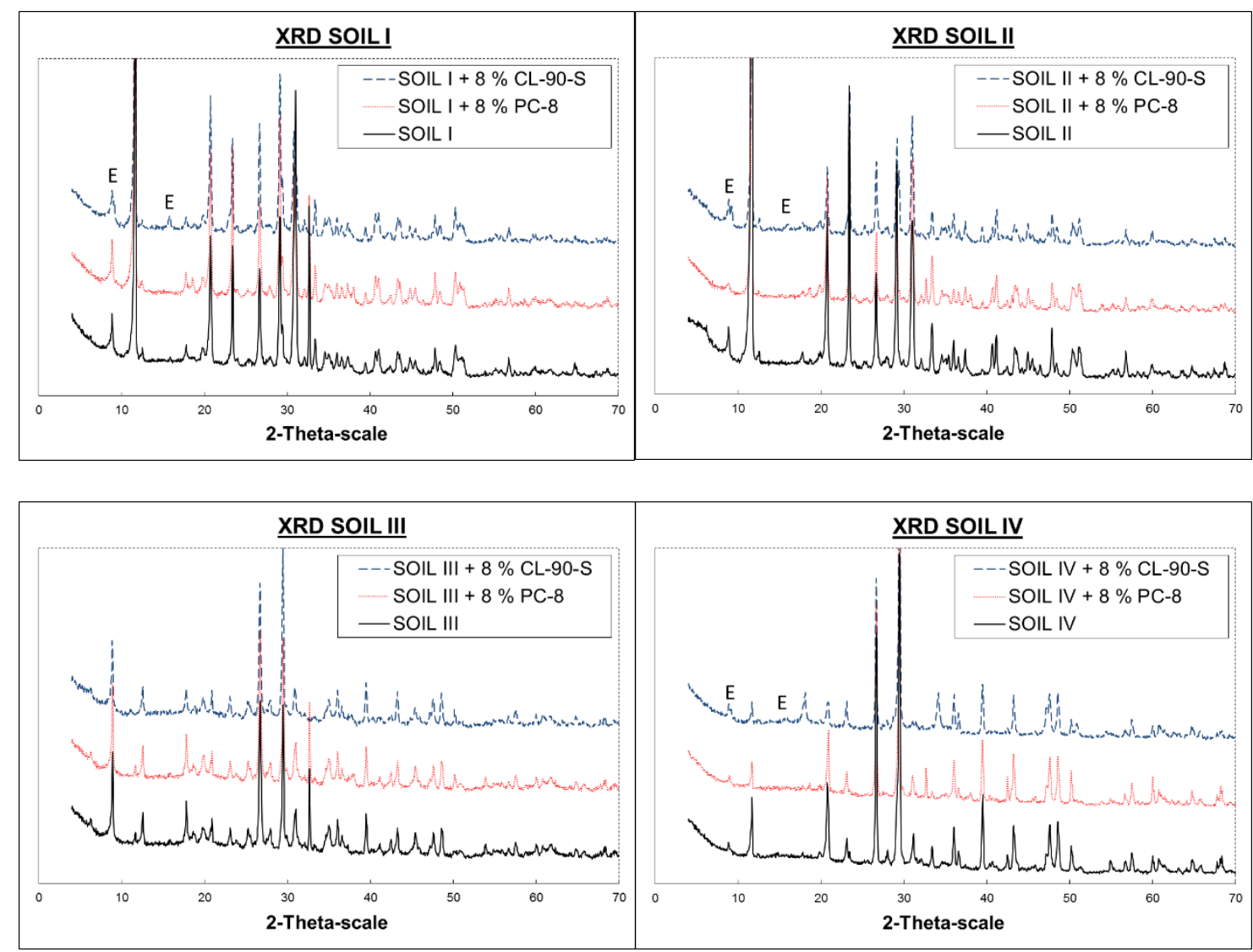

486

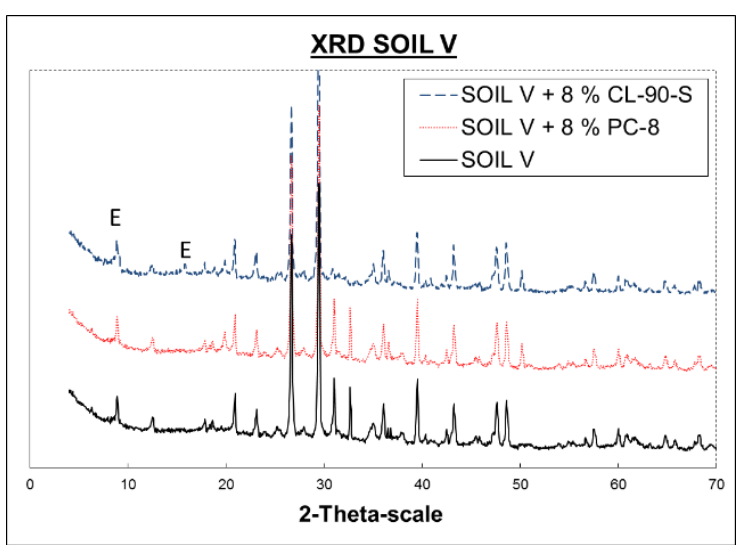


TABLES

490 